\title{
Mass production of law. Routinization in the transposition of European directives: a sociological- institutionalist account
}

\author{
Sara Berglund, leva Gange and Frans van Waarden
}

\begin{abstract}
This paper assesses the claim that there is a problem with delayed transposition of directives within the EU, using a new dataset on the transposition of directives in the fields of utilities and food safety regulation in the Netherlands, Germany, the UK, Spain and Greece. This dataset overcomes most of the problems that have plagued previous data. In 65 per cent of the cases transposition was delayed, and the average delay was seven months. There is thus indeed a problem with delayed transposition. In order to explain this problem, a sociological institutionalist approach is used. The findings point to the importance of administrative routinization. Whether or not transposition is accomplished with little delay depends on whether there are administrative departments with the explicit task to specialize in transposition, and whether they have had the time and resources to develop routines or standard operating procedures for doing so.
\end{abstract}

KEY WORDS Europeanization; policy learning; routines; sociological institutionalism; standard operating procedures; transposition.

\section{INTRODUCTION}

\section{Self-imposed policy constraints}

National policy-makers increasingly 'hit' against the constraints 'imposed' on them by the European Union (EU). The Dutch cannot expand their highway system as they like, because that brings them into conflict with European air quality standards; France can no longer resist liberalizing its energy markets; and the Greek government can no longer demand that baby food may only be sold in pharmacies.

European directives are largely responsible for such constraints. However, in order to become such constraints, they have to be transposed in national law in the member states, on their way from laws-in-the-books to laws-in-social-action. Transposition is an important form of 'Europeanization', of the influence of 'Europe' on its member states (Mény et al. 1996; Green Cowles et al. 2001; Héritier et al. 2001; Featherstone and Radaelli 2003). 
The European constraints on national policy-making are of course selfimposed: by the decision to join the EU, to accept the supremacy of European law, and to agree on specific directives in Brussels. Yet the 'hindrances' European directives form for national 'room for political manoeuvre' seem to become increasingly an incentive for resistance, and not only against those directives but to European integration in general. The 'no' vote of the French and Dutch electorates on the draft European constitution was partly motivated by an aversion to such Europeanization. In France, there is strong opposition to market liberalization. The Dutch feared European integration having become an uncontrollable process of production of legal constraints.

Considering the controversial nature of European regulation, member states might be tempted to frustrate transposition. Are delays hence politically motivated? Or are they more the result of cumbersome bureaucratic and political procedures, lack of attention and priority, or just plain inefficiency and sloppiness?

In this paper we will first investigate whether there are delays in the transposition of directives. We focus on directives in the policy fields of utilities (energy and telecommunications) and food quality regulation. Second, we will examine if there are differences between member states, and third, how the delays found can be explained.

\section{The research riddles}

There seem indeed to be problems with timely transposition. Complaints are frequently voiced in press, politics and business that member states fail to transpose directives in time. Newspapers reported recently that ten member states had not yet transposed the $2003 \mathrm{EU}$ directive banning cigarette advertising by the deadline of 31 July 2005, while every year 650,000 Europeans die prematurely of diseases linked to smoking. This could still be defensible under 'subsidiarity': why not leave member states some freedom regarding the health of their citizens? A different matter is where lack of transposition leaves unequal 'playing fields' for business, as with directives on access to utilities markets or food standards. Late transposition could give domestic business a temporary competitive advantage over producers in more obedient member states.

Such hindrances to free and equal competition have been a matter of political concern. Successive European Councils have stated that the transposition deficit should not exceed 1.5 per cent of the total number of directives. In order to gauge the performance of the member states the Commission maintains scoreboards, where it records the percentage of directives not yet transposed. The goal of a maximum of 1.5 per cent has never been reached. In May 2002, the percentage was at the lowest level of 1.8 per cent. Since then the transposition deficit has increased again, according to EU data (European Commission 2003a, 2003b, 2005). Although these percentages do not seem very high, they are taken very seriously by the Commission. Also, as Tallberg notes, a backlog of 5 to 10 per cent by a member state means that it has failed to 
transpose up to a hundred directives. Since the number of directives adopted each year lies somewhere between thirty and seventy, this number is quite high (Tallberg 2002: 624). Recently, the shortcomings of member states in transposing utilities directives have forced the Commission to initiate infringement procedures against them (e.g. in 2004 on electronic communications (European Commission 2004a, 2004b) or the opening up of their energy markets (European Commission 2004c)).

Transposition deficits have also attracted scholarly attention. Most studies on compliance with European Community (EC) law, in which quantitative data are presented, use two types of data from the European Commission, namely data on infringement proceedings or Commission scoreboard data on transposition progress (e.g. Haas 1998; Lampinen and Uusikylä 1998; Bursens 2002). However, as these data have many shortcomings, it is not sufficient to assess the alleged transposition deficit (Mastenbroek 2005b). Since the scoreboard performance records are only percentages of not yet transposed directives at a specific point in time, they do not tell us anything about the performance between these dates, or about delays in transposition. Furthermore, the data have an automatic upward bias, as the number of directives increases over time.

So far, only one dataset provides information on the length of the transposition process, and only for the Netherlands. Mastenbroek (2003) created a database of directives from 1995 to 1998 and the Dutch national instruments adopted for transposition. Using these data, Mastenbroek could measure the occurrence and length of delays.

We have created a similar dataset to compare whether there are performance differences between some member states - the Netherlands, Germany, the United Kingdom (UK), Spain and Greece - and some policy areas, namely utilities and food safety regulation. This is part of an effort to create a larger database on transposition, including also the areas of transport and social policy (see e.g. Haverland and Romeijn 2006; Kaeding 2005; Steunenberg and Rhinard 2005). The member states were selected on the basis of several criteria, making them representative for different categories of member states, such as large versus small, founding versus new members, and northern versus southern states. Likewise, the policy areas differ regarding important characteristics, notably age of policy area, and (related) type of regulations. This dataset allows us to assess not only whether member states are late with transposition, but also if so, how much and how often. These findings are presented in Section 2.

Provided that there are indeed transposition delays and performance differences between member states, the question is: why? This is the topic of sections 3 through 5. The burgeoning literature on compliance with EC law has focused on different explanatory factors. Mastenbroek (2005b) provided a recent overview. She identified three waves of research in this field. The first wave was mainly concerned with administrative factors, but lacked theoretical focus. The second wave drew on neo-institutionalist approaches and emphasized the role of 'fit' or 'misfit' between European policies and domestic policies and institutions. Because of the disappointing results of analyses focusing on 'misfit', a 
third research wave has focused on domestic politics in explaining compliance problems. Mastenbroek also points out that authors like Falkner et al. (2004) find administrative factors more important than 'opposition through the back door', and that new efforts try to explain non-compliance along sociological institutionalist lines. Our paper fits into this latter category.

The studies on compliance with EU law have produced quite a list of possible explanatory variables: corporatism (Lampinen and Uusikylä 1998; Mbaye 2001), number of veto players (Mbaye 2001; Giuliani 2003; Börzel et al. 2004), bargaining power in the Council (Mbaye 2001), citizens' support for the EU (Lampinen and Uusikylä 1998; Mbaye 2001), the rule of law (Börzel et al. 2004; Sverdrup 2004b) and so on. The results of these studies have been mixed. In a review of them, we found that only 45 per cent of the variables tested were confirmed (Berglund et al. 2005). Rather than testing our dataset with a large set of heterogeneous variables we have focused our analysis by using theory, namely sociological institutionalism, to select a few theoretically relevant explanatory variables.

In Section 4 we elaborate on differences between policy areas, and in Section 5 we pay attention to possible changes over time. Transposition has been a regularly occurring task for administrations, and that could have led, one might hypothesize, to the development of routines or standard operating procedures to facilitate transposition. Have countries learned from past mistakes? Does this show in better transposition performance as time progresses?

\section{TRANSPOSITION DELAY: DATASET, METHODOLOGICAL PROBLEMS AND FINDINGS}

\section{A new dataset}

We built a database of all utilities and food safety directives ever adopted by European institutions - directives both currently in force and no longer in force - with a deadline before 1 February 2004. The total number of directives is 250. As regards transposition, we did not include cases where the member state had not entered the EC at the time the directive was decided. The process of adopting all existing directives prior to membership differs, namely from transposing directives as a member state. Thus the number of directives to be transposed differs between member states, since they entered the EC at different times. The total number of cases (transposition of a directive in a member state) is 1088 .

Including all transposition records of the selected member states since the very first directive could bias the comparison, as member states have entered the Union at different times. Including the most recent directives could also bias the data, since their transposition might still be pending. To avoid these possible biases, we selected the date when the last country in the sample joined the EC as the starting point for this study, namely 1 January 1986, when Spain entered the EC. We set the end date at 1 February 1999. This 
limited dataset includes 565 cases, and will be used for our descriptive and explanatory analyses. However, the complete dataset will be used to study changes in transposition records of member states over time in Section 5.

Our database includes information about national transposition measures. This information was collected in three steps. We started with consulting the Commission's database Celex, which contains references to national transposition instruments. It has deficiencies, but it is a good start, as it is the only database common to all member states. Yet it should be remembered that it is an administrative rather than an academic database. With a different goal come also different data.

We did not restrict ourselves to Celex. The references to national legislation we found in it were checked and the respective national legislative texts were looked up in national legal databases or libraries and collected in folders. We used these national instruments for the further data we needed for the database, such as the date of adoption or the date of entering into force of the national instrument.

In a third step, we gathered information about national transposition instruments from other sources in cases where information was lacking in Celex. This was so in 30.4 per cent of the cases. Some references to national transposition measures could be found in Commission reports. Other information was collected from the individual member states. Some member states maintain databases that could be consulted, and for the remaining cases we received information directly from the ministries that had transposed the directive. Of course, these databases and the information from the ministries have drawbacks as well, the most common being that the information available is limited to a certain period or to the directives that were in force at the moment when the information was gathered. In these sources we found information for an additional 11.5 per cent of the cases. In total, information about national transposition instruments was found for 81.1 per cent of the cases. In an additional 5 per cent of the cases, all reported national legislation existed already before the adoption of the directive. We did not use these cases in the analysis, since strictly speaking, there was no transposition act here.

\section{Missing cases}

Although the completion rate for our database is high, there are still some cases for which we could not calculate delay. Missing cases in themselves are no problem. The crucial question is whether they are distributed randomly or bias the data. Are the missing cases those that have not yet been transposed or where delay is very great, or are there other, more mundane, reasons for their absence? Existing national legislation might have been considered sufficient and transposition not necessary, or the directive was transposed but no measure was reported (e.g. out of sloppiness or lack of administrative capacity of either the EU or member states).

For some cases the sources stated explicitly that transposition was not necessary. To find out whether other missing cases could be not yet transposed 
ones, we requested information from the Commission regarding whether or not the directives were transposed.

One Commission report on the transposition situation of all energy directives on 31 December 2002 revealed that - with two exceptions - all directives for which the deadline had passed (thirty-one directives) had been transposed by our five member states or transposition was not necessary. The exceptions were directives with deadlines in 2001 and 2002. Other reports we received gave a similar picture. Thus only directives of recent date are still pending. Since we do not include very recent directives in our analysis, we can confidently assume that most missing cases concern directives that have been transposed, or where transposition is not necessary.

Furthermore, in some years Celex information is more meagre than in others, and these years coincide with periods in which the responsibility for Celex was moved between directorates. This suggests that Celex completeness is related to manpower resources of the unit within the Commission responsible for the database. Hence we have good reason to assume that the distribution of missing cases in our database is random, and that it is due to administrative shortcomings by the Commission or the member states.

\section{Calculating delay}

Transposition delays are calculated by counting the days passed since the deadline of the directive until the first national transposition instrument was adopted. A negative number thus represents timely transposition, while a positive number indicates delay. An alternative strategy would have been to select the last instrument used. However, we decided to take the first national instrument for four main reasons.

First, the first instrument is most important, since it sets a process of transposition in motion. We have learned from examining the national transposition measures texts that the first instrument is not merely a superficial legal reaction but a substantial piece of legislation.

Second, and more important, choosing the last instrument involves some serious conceptual problems. It is not possible to know when transposition in a member state is complete merely by looking at references to national legislation in Celex or other sources. Additional measures are often reported long after transposition was basically completed. Some directives even require member states to report to the Commission further legal instruments adopted in the field, even if they are not necessary in order to complete transposition. Conceptually there is thus no such thing as a last instrument. Any new national legislation that overlaps with a directive has to be reported (or would have to be so) and would be a new transposition of the directive. There is always the possibility that new measures will be added later, and the first measure might in fact be sufficient in order to comply with the requirements of the directive.

Third, assessing when transposition is complete would require a different research strategy, namely a detailed comparison of the requirements of the 
directive and the contents of the transposing national legislation. Falkner et al. (2005) did so, and developed the concepts of 'essentially correct' and 'completely correct' transposition. However, even such a strategy is not without problems, since establishing when transposition is complete remains a matter of judgement. For example is, 80 per cent or 90 per cent completeness sufficient, or does completeness require 100 per cent?

Fourth, while the first instrument may not necessarily indicate that transposition is complete, using this indicator we can confidently answer the question if there has been a delay. Using the last instrument does not allow for such conclusions, since transposition might have been essentially completed by earlier instruments. Using the first instrument also has the advantage that we avoid the problem of exaggerating delays.

\section{Transposition performance}

Positive delays (transposition after the week of the deadline) were found in 65.3 per cent of the cases for which delay could be calculated. Of these cases, 60.9 per cent were transposed within one year after the deadline, 25.1 per cent between one and two years, and 14 per cent two years after or later.

The average delay if all cases are included (both cases with negative and positive delay) is 214 days (seven months). If only the cases with positive delay are included, the average delay is 397 days (thirteen months). The longest delay was 2,671 days (over seven years). Thus delays in transposition of directives are rather common and can be long.

The five member states included in the study have quite different transposition records in the time period selected, as may be seen in Table 1.

The Netherlands (NL) has the best transposition record followed by the UK, Spain (E) and Greece (GR). Germany (D) has the worst transposition record. This ranking remains the same regardless of whether the mean delay, the median delay, or the percentage of directives delayed is considered. For simplicity's sake, only the mean delay will be considered in the remainder of this paper.

Table 1 Differences in delays between the Member States (1986-1998)

\begin{tabular}{lcccc}
\hline & $\begin{array}{c}\text { Mean delay } \\
\text { in days }\end{array}$ & $\begin{array}{c}\text { Median delay } \\
\text { in days }\end{array}$ & $\begin{array}{c}\text { Percentage } \\
\text { of directives } \\
\text { delayed }\end{array}$ & $\begin{array}{c}\text { Number of } \\
\text { cases }\end{array}$ \\
\hline The Netherlands & 67 & -6 & 38.4 & 99 \\
Germany & 349 & 269 & 84.7 & 72 \\
The UK & 161 & -2 & 49.4 & 89 \\
Spain & 237 & 160 & 78.6 & 103 \\
Greece & 290 & 197 & 78.9 & 95 \\
Total & 214 & 107 & 65.3 & 458 \\
\hline
\end{tabular}

Source: Own data. 
We have established that there is indeed a problem with delayed transposition, and that there are in this respect differences between the member states. While this problem has diminished in recent years (see Section 5), the problem persists in some member states and policy areas.

\section{EXPLAINING TRANSPOSITION DELAYS}

\section{Sociological institutionalism}

Many existing quantitative studies on transposition (Lampinen and Uusikylä 1998; Giuliani 2003, 2004; Mastenbroek 2003) and infringement proceedings (Mbaye 2001; Börzel et al. 2004; Sverdrup 2004b) have tested quite a heterogeneous set of explanatory variables. The choice seems to be somewhat haphazard and lacks theoretical coherence. We intend to 'remedy' this by focusing on a few variables that can be theoretically derived from sociological institutionalism.

A basic assumption of this approach is that social actors are embedded in sets of institutions that structure their social action and behavioural choices. Institutions can be defined as formal and informal sets of mutual expectations between people, that have become more or less enduring, and that have crystallized into rule systems. These rules define roles and identities of social actors, and the criteria for actors to take up such roles. The role definitions are situationspecific. They define what is expected of oneself and others in specific situations. Actors are like judges: when they enter new situations they try to identify which rules apply to their situation and their own and others' roles. What is the appropriate behaviour here (cf. March and Olsen 1989)? What do others expect from them, and what can they expect from others? Many of these informal rules are followed automatically and unconsciously once the actors have been socialized in their community. The rules have become routines and conventions. It would be an enormous burden if social actors would have to identify all these rules consciously and decide whether they want to abide by them. Thus routines and conventions reduce complexity and increase efficiency of social action.

Ideal-typical rule systems are religion, cultural conventions, language, and for our purposes political and administrative conventions and law. Law is actually a formal codification of such mutual expectations regarding one another's behaviour, developed over a long period of time out of conventions, case law and statutory law, and is specific to a certain community, society or country. While rules structure behaviour, they do not fully determine it. Reasons for deviations from rules can be, for example, that rules are inconsistent or that there are not sufficient resources or competences to abide by them (March 1994: 74).

Political and administrative institutions distribute authority, power, duties and obligations over roles and situations. They regulate access to the political arena of people, issues, problems and solutions; they distribute resources and legitimacy among participants; they construct the physical, cognitive and 
moral conditions for political action; they influence perceptions of political actors of the reality in which they find themselves, their environment and their tasks; and they build a symbolic order for groups, for identification and for meaning.

Summarizing, sociological institutionalism emphasizes:

- the embeddedness of social action including actors' preferences and choice;

- the development of mutual social expectations into more stable rule systems, also called norms or institutions;

- insofar as social expectations concern expected action they develop into routines and conventions;

- these institutions subsequently form guides of social action;

- norm-, social frame- or institution-guided behaviour is seen as alternative to preference or interest-guided behaviour;

- the institutions are guides, but not determinants of social action. Actors interpret norms and can change them in the process, and they may not always be able to follow them.

\section{Independent variables}

From this theoretical perspective we have derived the following five variables for explaining transposition.

\section{Type of legal instrument}

Rule systems are of central importance in sociological institutionalism, and these systems may take the form of formal law. This is particularly the case in political decision-making which tends to be highly stylized and framed in law that prescribes the process that has to be followed. Political scientists often overlook this. As regards transposition, the legal instrument that is chosen defines the legislative procedure that has to be followed, and thus also identifies which actors get involved in the process and when, what their authority is, and sometimes also whether there is a time limit within which they have to intervene. The legislative procedure fixes in quite a formalized manner the mutual expectations between the members of the decision-making community. They know what each one's authority is, when they have to be heard or asked for a decision, how long one may have to wait for them and so on.

The choice of instrument itself is of course usually not entirely free for political and administrative actors, but is pre-structured in the institutional context within which they function, such as constitutional and administrative law and conventions.

The legal procedure by which transposition takes place is expected to affect the timeliness of transposition in at least two ways. First, it determines how many and which actors have access to the process, at which stages, and what their competences and means of influence are. Second, it defines the complexity of the legislative process and may set limits to the time which different actors 
have to make decisions. Thus in case formal law is used or required, more actors are involved and transposition may be expected to take longer.

\section{Respect for the rule of law}

Sociological institutionalism also emphasizes norm-guided behaviour. One social norm can be respect for formal legal rules, but its intensity may vary between countries. We assume that if there is a strong tradition of law abidance in a member state, the role models of political and administrative actors will be defined accordingly: they will consider it their duty to abide by the law, including the obligation to transpose European directives timely and correctly. A somewhat similar argument has been made recently by Falkner et al. (2005). In their ambitious study of the transposition of six labour law directives, they find that different cultures of compliance in the member state are important for the process of transposition. The variable 'rule of law', and also the following variable, have previously been used fruitfully to explain the number of infringement proceedings initiated against the member states (Börzel et al. 2004; Sverdrup 2004b).

\section{Organizational capacity to create and follow norms, or government effectiveness} Following sociological institutionalism, political actors should not only be willing, but also capable of abiding by the law. That is, they should be able to take swift, effective and efficient decisions. That in turn depends on governments having resources, expertise, bureaucratic organization and other sources of power. Such government capacity for effectiveness will obviously facilitate speedy transposition, assuming, of course, a willingness of the actors to transpose. Governments that are used to expect compliance by others to their decisions may also be more receptive to the $\mathrm{EU}$, having the right to expect compliance by them.

\section{Period of five years}

According to sociological institutionalism, rule systems are likely to develop over long periods of time. Policy learning includes the development of government capacities specific to the task of transposition. One of these capacities can be the development of legislative routines and institutions that speed up transposition.

Typically, transposition lends itself well to routinization. It is a rather special form of national lawmaking. It follows the decision-making processes in the various national political-administrative arenas, but there is little room for manoeuvre for member states. The content of regulation is to a certain extent prescribed. For all member states the input is more or less the same: the directive. Some do leave room for variation, where they set only minimum or maximum standards, or where the wording is so vague that several interpretations are possible. However, the contours are largely fixed. National regulation should be in agreement with the directive, enacted within the transposition deadline set. What can differ more is the throughput: the process and form by which the input, the directive, gets translated into output, national legislation. 


\section{Policy area}

We choose to collect data on two rather different policy fields: utilities and food safety regulation. They differ in several respects.

First, as regards the topics of regulation. Utilities directives have usually been concerned with market creation, with the opening of new markets that took the place of formerly public monopolies in telecommunications and energy. Subsequently, the directives have concerned the structuring of competitive positions and relations between the various market players in order to ensure that real competitive markets would develop, as well as with the position, tasks and authority of the new regulatory agencies, which have to maintain these as real markets. Food directives have usually been concerned with market regulation, with setting standards for products on already long-existing markets: with the quality, safety, or labelling of products, meant to reduce the risks and uncertainties for transaction partners and with increasing the transparency of these markets, in order to create or maintain a 'level playing field' for customers and suppliers from different member states in an integrated market.

Linked to this are some other differences. Food safety regulation is an old policy field. Statutory food regulations can be as old as food markets, as they concern public health. In ancient Greece and Rome there were already laws against the colouring and flavouring of wine. In Western Europe laws against adulteration of food and drink arose in the later Middle Ages. Famous landmarks are the British impure food laws from 1226 or the Bavarian Reinheitsgebot for beer from 1516. The first 'modern' legislation dates from the latter half of the nineteenth century, with the beginning of large-scale industrial food production and distribution: in Britain from 1860 (the Food Purity Law), extended in 1874, in Germany 1879, France 1885, Belgium 1890 and the Netherlands 1889 (van Waarden 2006).

Utilities regulation is a much newer policy field. First, the products, services and markets are new. Telecommunications and electricity did not exist 150 years ago. Second, for a long time the state regulated these sectors through its position as the one and only owner/provider of the services, i.e. through internal hierarchic control over the public telephone and electricity companies. Concerns for fair and equal competitive positions were irrelevant where there was no market, and thus entered the arena later.

Being an old concern of state regulation, the food sector has well-established public and semi-public institutions: national framework laws, agencies and administrations, regulatory routines, and powerful interest associations. These established institutions, institutes and interests could of course also be a force frustrating new regulations. However, as European directives are often in line with domestic traditions, it could be hypothesized that these institutions will facilitate transposition. Existing framework laws may permit governments to use lower level legal instruments to transpose directives, which could allow for speedier transposition. The existence of well-developed and well-resourced agencies implies that there are domestic actors that can carry out the administrative tasks involved in transposition, and they could even find a new reason for existence in them. They may already have developed legislative routines that could also be applied to transposition. 
By contrast, in a new policy area such as utilities regulation, such institutions, institutes and interests still have to be developed. Framework laws do not yet exist, thus forcing governments to use primary legislation to transpose directives. This is confirmed by our data. In 27.3 per cent of the cases, utilities directives were transposed by primary legislation, while food safety directives were only transposed by primary legislation in 1.3 per cent of the cases. In addition, new administrative divisions and agencies for the utilities sector, which could find a task in transposition, have yet to be developed, and they still lack standard operating routines. All these factors are likely to produce delays in transposition.

A central difference is thus the different age of the policy fields, which might indicate differing levels of institutional development, and which links this variable to the previous variable 'period of five years'.

Another difference between the policy areas concerns the character of the directives adopted. The directives concerning food safety are usually rather technical, while the utilities directives are more encompassing and politicized. Hence transposition of utilities directives may be expected to be more problematic.

\section{Operationalization}

Regarding the variable 'type of legal instrument', four categories of legal instruments could be distinguished, namely:

(1) Primary instruments or statutory law, involving the administration, the government and Parliament (NL: Wet; D: Gesetz; UK: Act of Parliament; E: Ley; GR: Law)

(2) Secondary or lower level instruments. These consist of:

- Orders in Council or presidential or royal decrees, which involve the government as a whole (NL: Algemene Maatregel van Bestuur, E: Real Decreto, GR: Presidential Decree;

- Ministerial decisions or decrees, which are enacted by an individual cabinet minister (NL: Ministeriele regeling; D: Verordnung; UK: Regulations, Orders, Ordinances, or Statutory instrument; E: Orden; GR: Ministerial Decision;

(3) Tertiary instruments, i.e. lower level administrative decisions, such as Orders of Statutory Trade Associations (NL), Mitteilungen and Bekanntmachungen (D), Circulars (UK) or Resoluciones (E).

However, secondary instruments, such as presidential/royal decrees and ministerial decisions, are difficult to compare across member states. The legislative procedures linked to them differ by country, but the greatest problem is that in some member states the category 'presidential/royal decree' does not exist. Therefore, we included both types of secondary instruments, 'presidential decrees' and 'ministerial decisions', in one category. Hence, we compare formal law, which has to go through a full parliamentary procedure, secondary legislation, which is adopted by the Cabinet or a single minister and which sometimes passes through a limited parliamentary procedure, and tertiary instruments. 
In order to operationalize variables 2 and 3, one option was to use indicators for the rule of law and government effectiveness from the World Bank report 'Governance matters III: governance indicators for 1996-2002' (Kaufmann et al. 2003). Sverdrup (2004b), for example, used these indicators. The governance indicators in the World Bank study are based on aggregations of indicators from a number of sources, such as surveys and risk assessments for investors.

The indicator for 'rule of law' includes perceptions of the incidence of crime, the effectiveness and predictability of the judiciary, and the enforceability of contracts. Unfortunately, it includes many sub-indicators that are too distant from the issue of transposition to be of relevance to this study. Some examples are 'risk of kidnapping of foreigners', 'money laundering', 'quality of police' and 'black market'. Therefore, the indicator 'justice' from the World Competitiveness Yearbook published by the International Institute for Management and Development (1996-2003), was considered more appropriate for this study. This indicator is one of the sub-indicators for the World Bank 'rule of law' indicator, and it is based on surveys among local and foreign enterprises about perceptions of fairness of the administration of justice.

The 'government effectiveness' indicator in the World Bank study was judged to be of relevance to our study. It measures aspects such as quality of the bureaucracy, the competence of civil servants, the independence of the civil service from political pressures, and the credibility of the government's commitment to policies. Since it is a well-defined measure of government effectiveness it was used to operationalize the variable 'government effectiveness' for this study.

The process of learning over time was operationalized by indicating in which period of five years a directive was adopted. The variable policy area consists of the two categories 'food safety' and 'utilities regulation'.

The independent variables used in this study are thus 'type of legal instrument', 'justice', 'government effectiveness', 'period of five years' and 'policy area'. As control variable, the variable 'member state' is used.

\section{Analysis}

\section{Applied method}

Since the data are grouped by the variable 'member state', it is necessary to control for this in the analysis, especially since some of the variables that will be tested are on the member state level. If the grouped structure of the data is not controlled for, there is a risk of getting inflated Type I errors, and thus overestimating the significance of the explanatory variables. We controlled for the effect of the grouping variable by using the ANCOVA method, and by including the grouping variable as a fixed factor. In principle, multiple regression with a dummy variable could just as well have been used, since it is essentially the same method (Miles and Shelvin 2001). For this study, the ANCOVA method was selected since it is more convenient to use for an analysis with many categorical variables.

Since the dependent variable 'delay' does not show a normal distribution but is positively skewed, the log of the dependent variable was taken. This resulted in an approximately normal distribution, apart from one extreme outlier. Since this 
outlier distorted the data, it was removed. The case was the food directive 1998/53/ EC (Sampling methods and methods of analysis for certain contaminants in foodstuffs), which was transposed by the Netherlands 691 days before the deadline.

\section{Results}

The results of the analysis are presented in Table 2

The variable 'policy area' has a significant effect, and thus timeliness of transposition is affected by characteristics of the policy areas. Directives in the area of utilities are, as expected, associated with more delay.

The results for the variable 'period of five years' shows that the time period in which a directive was adopted matters for timeliness of transposition. Compared

Table 2 Results based on ANCOVA analysis

\begin{tabular}{|c|c|c|c|}
\hline Variable & Category & $B$ & $F$ \\
\hline Corrected model & & & $6.818^{* * *}$ \\
\hline Intercept & & & $188.877^{* * *}$ \\
\hline \multirow[t]{5}{*}{ Member state } & $\mathrm{NL}$ & .130 & .902 \\
\hline & $\mathrm{D}$ & .346 & \\
\hline & UK & .101 & \\
\hline & ES & .074 & \\
\hline & GR & $\begin{array}{r}\mathrm{O} \text { (reference } \\
\text { category) }\end{array}$ & \\
\hline \multirow[t]{2}{*}{ Policy area } & Utilities & .065 & $10.791^{* *}$ \\
\hline & Food safety & $\begin{array}{r}\mathrm{O} \text { (reference } \\
\text { category) }\end{array}$ & \\
\hline \multirow{3}{*}{$\begin{array}{l}\text { Type of legal } \\
\text { instrument }\end{array}$} & Formal law & .170 & 1.055 \\
\hline & Secondary legislation & .151 & \\
\hline & Tertiary instruments & $\begin{array}{r}\mathrm{O} \text { (reference } \\
\text { category) }\end{array}$ & \\
\hline \multirow[t]{3}{*}{ Period of five years } & $1985-1989$ & .144 & $17.908^{* * *}$ \\
\hline & 1990-1994 & .059 & \\
\hline & 1995-1999 & $\begin{array}{r}\mathrm{O} \text { (reference } \\
\text { category) }\end{array}$ & \\
\hline $\begin{array}{l}\text { Government } \\
\text { effectiveness }\end{array}$ & - & -.120 & $6.218^{*}$ \\
\hline Justice & - & -.005 & .021 \\
\hline $\begin{array}{l}\text { Member state* } \\
\text { Type of legal } \\
\text { instrument }\end{array}$ & - & - & $2.239 *$ \\
\hline R squared & & & .212 \\
\hline Adjusted R squared & & & .181 \\
\hline $\mathrm{n}$ & & & 457 \\
\hline
\end{tabular}

Notes: Dependent variable: $\log$ of delay in days, ${ }^{*}=p<.05,{ }^{* *}=p<.01$, $* * *=\mathrm{p}<.001$. 
to 1995 to 1999 , directives from 1990 to 1994 were transposed with more delay, and in the period 1985 to 1989 delays were even longer. While other variables relating to time may also have contributed to this development, this indicates that the member states have improved their ability to transpose directives in a timely fashion over the years.

The influence of the independent variable 'government effectiveness' on transposition delays is significant and has the expected negative sign. Thus the effectiveness of a government does indeed affect the transposition record. Although the variable 'justice' does have the expected negative coefficient, this effect is not significant. The reason could be that, although we used the best data available, the variable is rather indirectly measured. What we are really interested in is the respect for the rule of law among civil servants, but the only indicator available was 'fairness in the administration of justice' as perceived by investors. Another reason for the absence of a significant effect could be that there is not enough variation on this variable among the selected member states. In all of them, respect for the rule of law is quite well established.

The variables 'member state' and 'type of legal instrument' were not significant. However, there is a significant interaction effect involving these two variables. This interaction effect is presented in Figure 1, which shows that in most member states, the use of formal law for transposition is indeed associated with more delay than are secondary instruments, which are in turn associated with more delay than are tertiary instruments. However, this effect does not hold for all member states. The notable exception is Spain, where formal laws are associated with less delay than secondary instruments. Another exception is Germany, where tertiary instruments produce most delay. However, some caution is necessary when interpreting these effects. First, there were very few cases where the UK and Greece used formal law for transposition, and the differences between cases where law was used and where secondary instruments are used is also not very large in these member states. Second, in Germany and the UK tertiary instruments were rarely used. However, the surprising effect of the use of formal law in Spain remains.

Below, two of the variables that were found significant in the analysis, namely 'policy area' and 'period of five years', are elaborated further.

\section{DIFFERENCES IN DELAY BY POLICY SECTOR}

The analysis showed that utilities directives are transposed with more delay than are food safety directives. This supports the hypothesis that transposition goes faster in an older policy field. The characteristics of the directives may also be relevant. As mentioned above, food safety directives are more technical in nature and less politicized than are utilities directives, and this may make the process of transposition less complicated for food safety directives.

Table 3 demonstrates this difference, and also shows that leaders and laggards differ in the two policy sectors. In utilities regulation, the UK is the leader and Greece the laggard. In food safety, the Netherlands is the best transposer, while Germany has the worst transposition record. This again confirms the hypothesis 


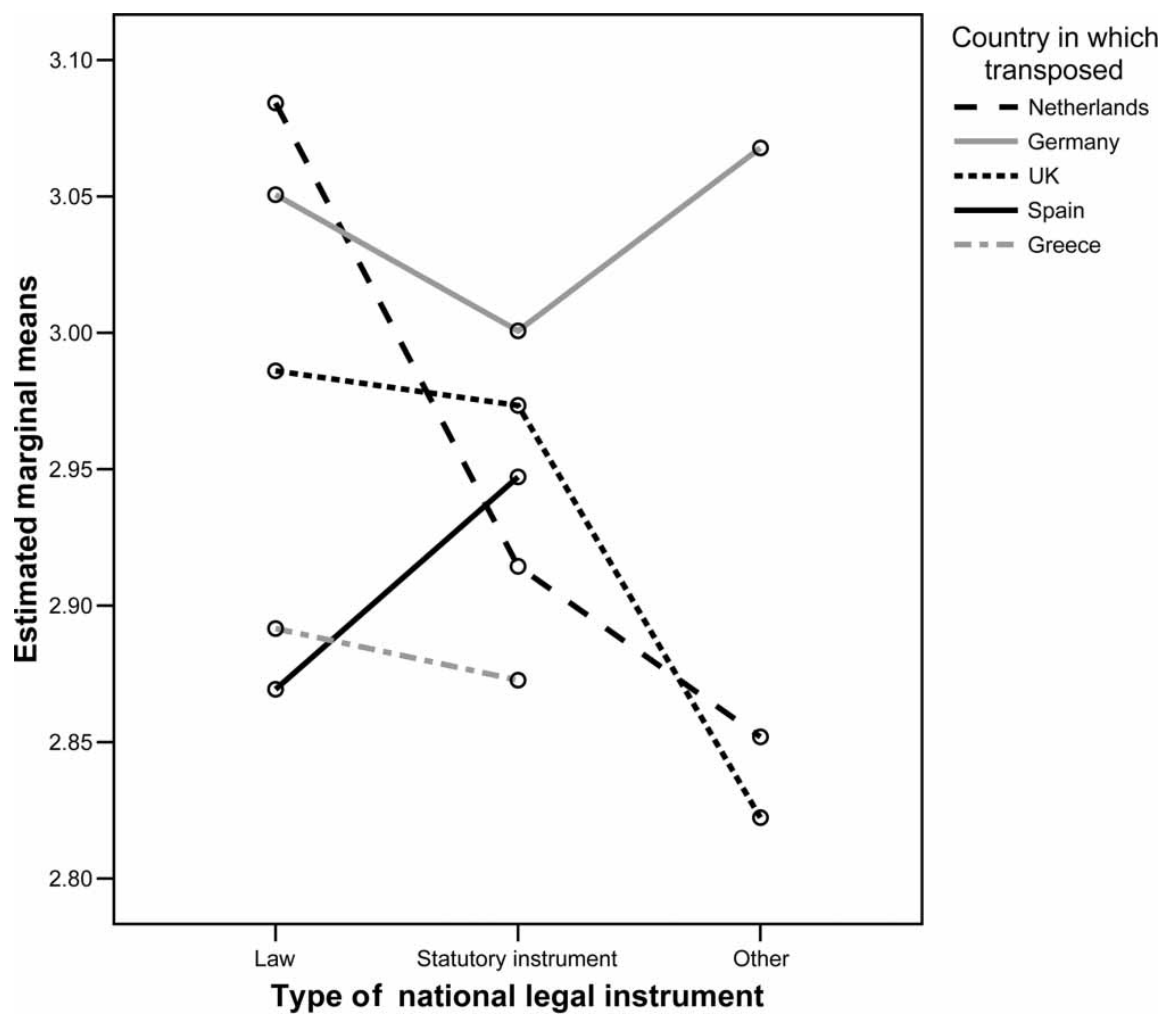

Figure 1 Interaction effect for 'member state' and 'type of legal instrument' Source: Own data.

Note: Non-estimable means are not plotted.

formulated above. Britain was the first country in Europe to liberalize its utilities markets and already has the longest experience with sectoral specific regulation. Hence there the institutions, institutes and interests have been longest in place, allowing the country to take a leading role in the transposition of utilities directives, the more so, since the directives usually go in the direction in which Britain has already gone: towards more market liberalization, i.e. roughly a 'goodness-of-fit' case (Knill and Lenschow 1998; Börzel 2000; Héritier et al. 2001). The leader in transposition of food directives, the Netherlands, fits this picture well. It has the largest and best-established agricultural and food industry (in relative terms) with many institutions, institutes and interests developed over the last century and a half, allowing for legislative routines within framework legislation. In addition, as it has a highly productive and competitive industry it tends to profit most from a 'level playing field' all over Europe.

Since the utilities sector is actually made up of the two sub-sectors, telecommunications and energy, we also examined if there are differences between them. There are indeed, as Table 3 shows. Mean delays in telecommunications directives' 
Table 3 Mean delays in number of days by member state and policy area

\begin{tabular}{|c|c|c|c|c|c|c|c|c|}
\hline & \multicolumn{2}{|c|}{ Food safety } & \multicolumn{6}{|c|}{ Utilities } \\
\hline & \multirow[b]{2}{*}{ Mean } & \multirow[b]{2}{*}{$N$} & \multicolumn{2}{|c|}{ Total } & \multicolumn{2}{|c|}{ Telecom } & \multicolumn{2}{|c|}{ Energy } \\
\hline & & & Mean & $N$ & Mean & $N$ & Mean & $N$ \\
\hline Netherlands & 0 & 61 & 175 & 38 & 411 & 19 & -62 & 19 \\
\hline Germany & 328 & 47 & 389 & 25 & 481 & 10 & 328 & 15 \\
\hline UK & 164 & 61 & 156 & 28 & 228 & 13 & 93 & 15 \\
\hline Spain & 218 & 65 & 269 & 38 & 258 & 19 & 280 & 19 \\
\hline Greece & 228 & 67 & 439 & 28 & 709 & 15 & 128 & 13 \\
\hline Total & 183 & 301 & 275 & 157 & 409 & 76 & 150 & 81 \\
\hline
\end{tabular}

Source: Own data.

transposition are over 2.5 times as large as for energy directives. Except for Spain, this greater speediness of transposition of energy directives holds also for the individual countries. The difference is great, especially in the Netherlands and Greece.

The explanation is likely that liberalization has progressed further in telecom than in energy. Telecom liberalization is not old enough to have produced institutions such as framework laws and well-established and routinized administrative agencies which could facilitate transposition. But liberalization has progressed far enough in order for there to be some real liberalization. This implies three things: (1) the European directives concern major policy changes, which are controversial both in politics and the administration; (2) liberalization is already real enough that it has produced many teething troubles; (3) there is already domestic regulation in the making, and European directives complicate this, in the sense that one is waiting for the other. All, namely controversy, teething troubles and mutual waiting, are likely to have frustrated transposition.

By contrast, energy market liberalization has progressed at a much slower pace, and most of the directives do not concern major policy decisions of privatization and liberalization, but issues such as energy efficiency and energy labelling of household appliances. There are thus not yet enough detailed problems or new domestic legislation to complicate transposition.

\section{CHANGES OVER TIME: LEARNING AND THE DEVELOPMENT OF ADMINISTRATIVE ROUTINES}

Let us also elaborate on the changes over time, as they bear on the development of routines. The analysis of data from 1986 to 1999 indicated that more recent time periods show less delay. Looking at our full dataset fortifies this picture. Table 4 shows that the average delay has decreased over time. In the $1960 \mathrm{~s}$ the average delay was 2,023 days, in the 1970s 457 days, in the 1990 s 158 days, while since 2000 there is on average no delay. Transposition happens even on average one month before the deadline. Again on average, there no 
Table 4 Transposition delay over time (1960-2004)

\begin{tabular}{lcr}
\hline Time period & Mean & $N$ \\
\hline $1960-1969$ & 2023 & 13 \\
$1970-1979$ & 457 & 115 \\
$1980-1989$ & 460 & 181 \\
$1990-1999$ & 158 & 416 \\
$2000-2004$ & -32 & 161 \\
Total & 251 & 886 \\
\hline
\end{tabular}

Source: Own data.

longer seems to be a compliance problem. The general average scores hide differences between countries and policy areas. Although positive development may be observed in all five countries under investigation, there are differences in the extent of the improvements (Figure 2). The Netherlands, the UK and Greece have moved from substantial delays at the beginning of their membership to average transposition well in advance of the deadline. Spain has also improved its transposition speed, but the mean delay remains in positive

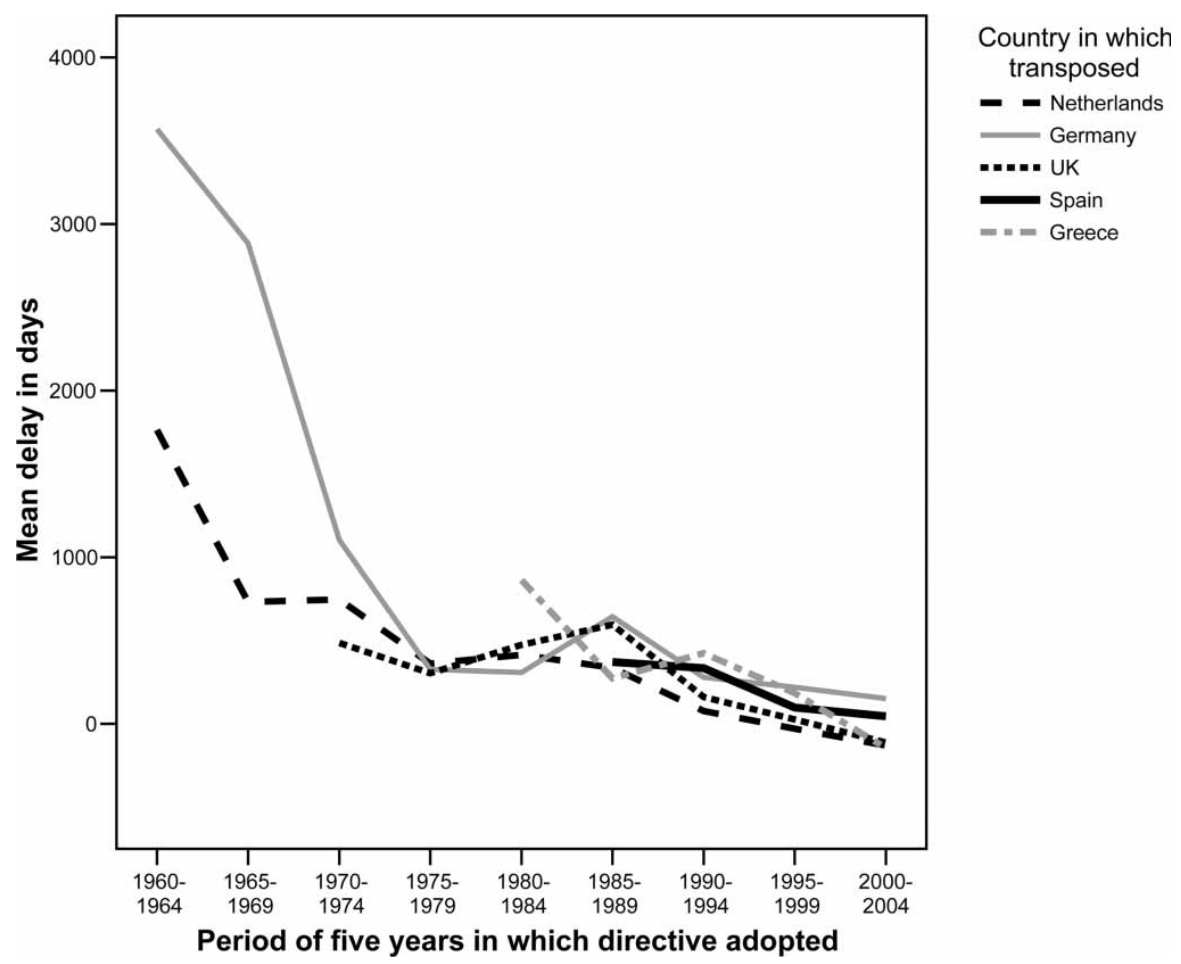

Figure 2 Mean transposition delay in days over time in five member states Source: Own data. 
numbers: forty-five days. Germany also shows improvement concerning the transposition delays, but the average delay is still 152 days in this millennium.

Figure 3 shows the development of the transposition record in the five member states during the period 1986 to 1999 . This shows more clearly that the development over time in Greece has had its ups and downs.

Figure 4 (covering the period 1986 to 1999) shows that the decline in delay has gone further and faster in the old policy field of food safety than in utilities regulation. Apparently, developing standard operating procedures is easier in an old and stable policy field.

The decrease in delay over time is probably the result of policy learning and the development of administrative routines. By learning, we mean that actors learn from mistakes and other shortcomings they have experienced, and which have confronted them with problems they would have liked to avoid, such as bad publicity or losing face. Learning thus means choosing those alternatives that make them get 'the carrot' or avoid the 'stick'. Eventually, the stimuli that cause positive responses can produce routine behaviour. In our case that would also find expression in the development of new institutions that facilitate, channel or evoke such routines.

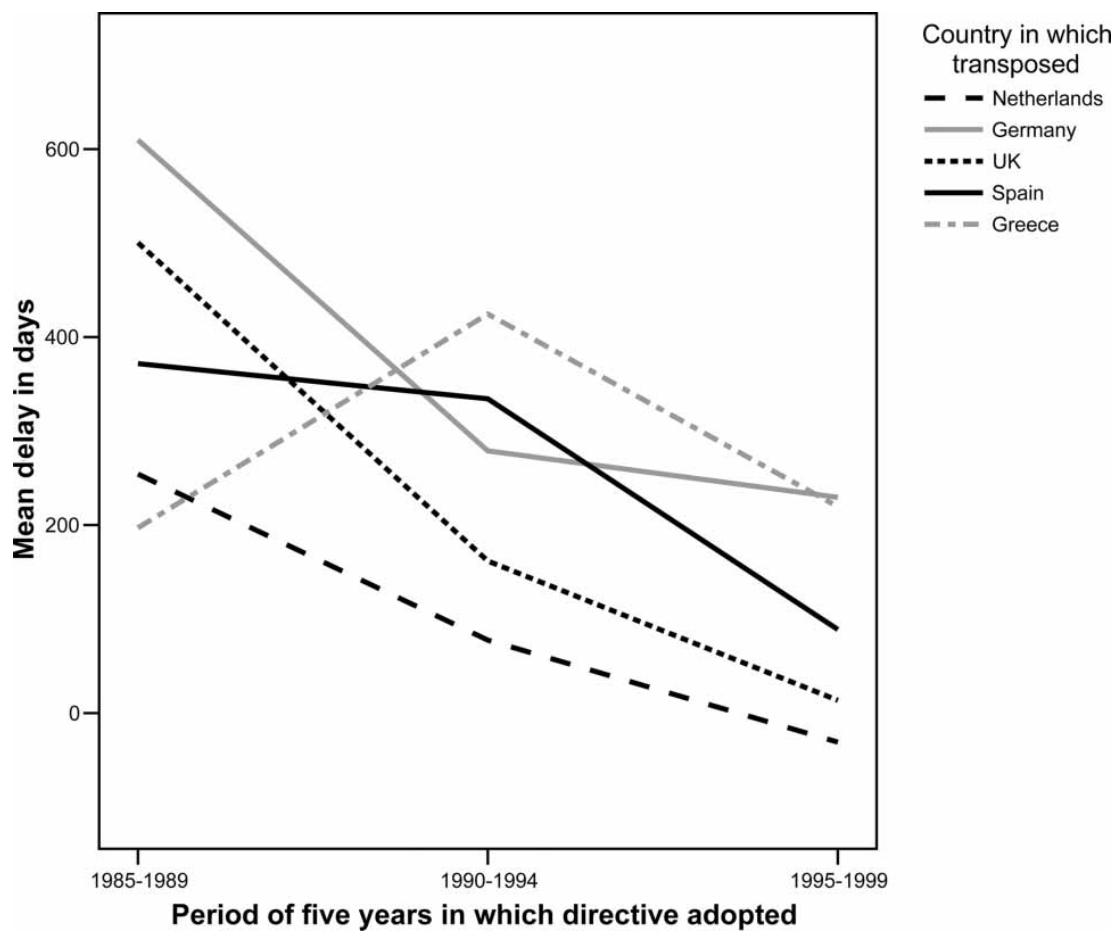

Figure 3 Mean transposition delay in days over time in five member states (19861999)

Source: Own data. 


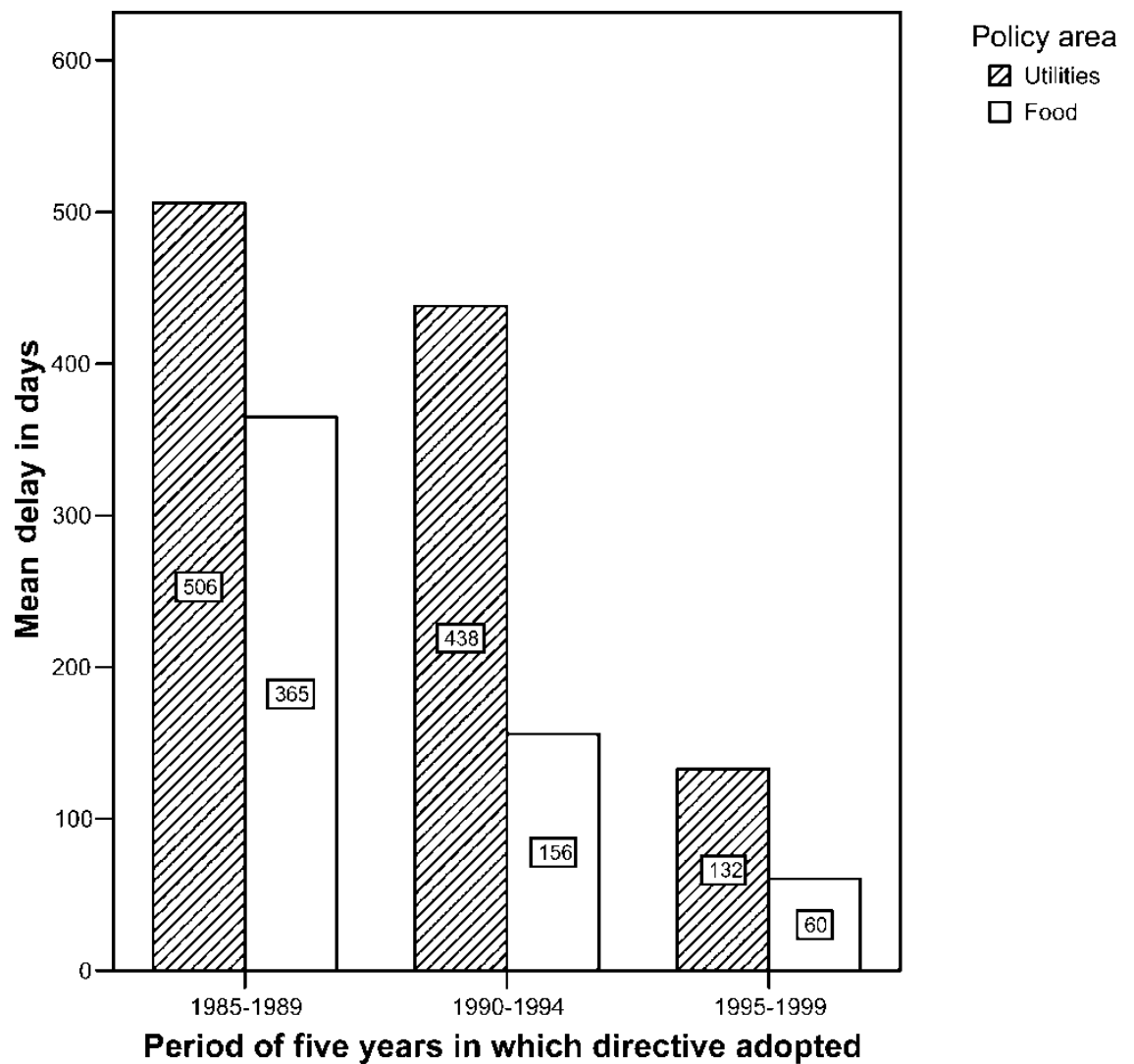

Figure 4 Mean delay in days per policy sector over time Source: Own data.

Learning can be both positive and negative. Positive, in the sense that actors who frequently have to perform the same activity, in time develop shortcuts and routines to do so more effectively and efficiently. Negative, in the sense that actors learn from mistakes and bad experiences. In policy-making incidents and accidents can give rise to such learning.

The incidents may involve blaming and shaming by 'significant others' for policy-makers. Benchmarking, as the European Commission does by regularly publishing a scoreboard, confronts member states with bad performance, as does the initiation of infringement procedures. The publication of research findings from legal scholars and social scientists and scandals such as the Dutch Securitel case $^{1}$ can have the same, though less intended, effect (NRC Handelsblad 1997a, $1997 \mathrm{~b}, 1997 \mathrm{c}, 1997 \mathrm{~d})$. These then give rise to publicity and questions by Members of Parliament.

Indeed, several countries have brought about institutional change. They have modified and streamlined legislative procedures used for transposition 
instruments and created conditions to ensure that transposition not only occasionally, but also regularly and continuously, gets higher priority. Thus the Dutch government has, following the aforementioned scandal, created an organization with initiation, coordination and monitoring responsibilities regarding transposition, and has also modified its 'Aanwijzingen voor de Regelgeving' (Directions for Rule-making) and changed legislation and 'standard operating procedures' in such a way that:

- now transposition is already started by the co-ordination body even before the directive has actually been enacted by the European authorities, namely at the moment that a 'common position' has been agreed to in Brussels;

- stricter time limits are set for actors involved in the various legislative procedures;

- information about transposition is spread more effectively, thus enabling continued naming and shaming within the government administration;

- in some ministries the negotiation and transposition phases are better integrated (e.g. by placing the domestic actors (the policy lawyers active in negotiation and the legislative lawyers responsible for transposition) in one and the same ministerial department; or even by having both activities done by the same persons). This facilitates or saves on information exchange (information from interviews with involved civil servants (see also Mastenbroek 2005a). Finally, various governments have enacted more enabling legislation, allowing administrations to transpose directives more frequently through lower level instruments.

The fact that this type of legislation has and is being done by twenty-five different countries creates special conditions for learning. Countries can learn from each other's experiences, and try to imitate what they perceive as 'best practices' or avoid 'bad practices'. The institutional changes made for transposition may even affect the normal domestic legislative procedures. Indeed, quite a special case of 'Europeanization' of national institutions.

All such institutional changes are detailed specifications of 'government effectiveness', now specified for transposition. However, the fact that some governments are able and willing to bring about such institutional changes can be considered an expression of a broader form of 'government effectiveness' as included in the quantitative indicator that we used in Section 3.

\section{CONCLUSION}

Our finding that transposition delays are affected by policy area, governments depending on their effectiveness, legal instruments used ${ }^{2}$ and the passage of time, can probably be reduced to one and the same underlying factor: the existence of administrative routines that allow for effective, efficient and fast production of law. Such routines are facilitated by the presence of institutions such as framework laws that allow for the use of lower level instruments. Whether or not such routines and institutions exist depends in turn on time. Time is needed for such routines and institutions to develop. 
An older policy field such as food safety has had more time to develop such routines and institutions. That delays are shorter in more recent time periods points also to the importance of time. As time has passed, member states have gained more experience with transposition, and have had time to develop routines that facilitate transposition. However, some learn quicker than others, depending partly on their degree of 'effectiveness', as defined and operationalized by the World Bank such as competence, independence and credibility of the public administration. In addition, effective governments - read professional public administrations - are themselves in part the product of time. They are typically found in countries with longer histories of state formation, which have had time to develop professional bureaucratic and legal organizational 'machines' for the production of law. Time has produced highly differentiated public state organizations, recently even with departments specialized in the task of transposition, and which through learning from experience have developed standard operating procedures and supporting institutions to transpose directives that allow for quick, effective and efficient mass production of regulations.

The task is indeed one of mass production. In the period 1974 to 1995 , approximately a thousand directives were adopted (Golub 1999). This equals on average about fifty directives per year. Assuming that all twenty-five member states had to transpose these directives and that they used on average two national instruments per directive, ${ }^{3}$ this means that 50,000 national legal instruments were produced in order to transpose the directives produced only during that time period.

Notwithstanding the frequently controversial nature of European directives - as pointed out at the beginning of this paper - political obstruction does not seem to be the main cause of transposition delays. Delays rather seem to be the consequence of administrative ineffectiveness, lack of experience, and lack of political and administrative priority. However, as time passes governments develop the organizations and routines for more effective and swifter transposition. One illustration of this is that some of the most Eurosceptic countries have the best transposition records. In our sample, this includes the UK all along, and the Netherlands given the recent twothirds no-vote on the European constitution. Other examples pointed out in the literature are the Scandinavian member states (Sverdrup 2004a). These member states are not only Eurosceptic, they also have effective and efficient government administrations. Thus the constraints on national political choice imposed by European law are also in this sense self-imposed: directly by efficient national public administrations taking their obligation to transpose European directives seriously.

Biographical notes: Sara Berglund is a Ph.D. candidate at Utrecht University, the Netherlands. Ieva Gange is a Ph.D. candidate at Utrecht University, the Netherlands. Frans van Waarden is Professor of Policy and Organization at Utrecht University, the Netherlands. 
Addresses for correspondence: Sara Berglund, Utrecht University, Faculty of Social Sciences, University College, PO Box 80145, 3508 TC Utrecht, The Netherlands. Tel. +31(0)302535883. Fax. +31(0)302539905. email: s.berglund@fss.uu.nl/Ieva Gange, Utrecht University, Faculty of Social Sciences, University College, PO Box 80145, 3508 TC Utrecht, The Netherlands. Tel. +31(0)30 2535884. Fax. +31(0)30 2539905. email: i.gange@fss.uu.nl/Frans van Waarden, Utrecht University, Faculty of Social Sciences, University College, PO Box 80145, 3508 TC Utrecht, The Netherlands. Tel. +31(0)30 2534820. Fax.+31(0)30 2539905. email: f.vanwaarden@fss.uu.nl

\section{ACKNOWLEDGEMENTS}

This paper is an outcome of a larger project on 'Analysing European Union policies: the transposition of directives', undertaken by researchers from the University of Leyden, the Free University of Amsterdam, the Radboud University of Nijmegen and Utrecht University, all in the Netherlands. We would like to thank the Netherlands Organization for Scientific Research NWOMAGW for financial support (project numbers 403-01-502 and 403-01504). Thanks go also to the other participants in this research group for the inspiring discussions we have had, and which contributed to the ideas developed in this paper. They are: Antoaneta Dimitrova, Markus Haverland, Michael Kaeding, Ellen Mastenbroek, Mark Rhinard, Bernard Steunenberg (all Leyden University), Kees van Kersbergen (Free University of Amsterdam), and Marleen Romeijn (Radboud University Nijmegen).

\section{NOTES}

1 This was not a problem of transposition per se, but one of implementation and enforcement of a transposed directive. One directive required member states to notify the Commission of new national technical standards so that it could evaluate their consequences for free trade. The directive was transposed, but actual implementation remained lax. One Dutch standard case -Securitel - came before the European Court of Justice (ECJ) and it ruled that because this standard was not notified, it was void. Societal actors could not be bound by it. In searching its files the government found that over 400 standards had not been notified, and an avalanche of liability suits threatened. This focused legal, public and political attention on the legal responsibilities of the Dutch government towards the Union, and the serious (financial) consequences of default.

2 This effect does not hold for all member states.

3 The average number of national instruments used for transposing one directive in our database was 1.73 .

\section{REFERENCES}

Berglund, S., Gange, I. and van Waarden, F. (2005) 'Taking institutions seriously. A sociological-institutionalist approach to explaining transposition delays of European food safety and utilities directives', Paper presented at the European Consortium for Political Research (ECPR) Joint Sessions, 14-19 April, Granada, Spain. 
Börzel, T.A. (2000) 'Why there is no "southern problem”. On environmental leaders and laggards in the European Union', Journal of European Public Policy 7(1): 141-62.

Börzel, T.A., Hofmann, T. and Sprungk, C. (2004) 'Why do states not obey the law? Non-compliance in the European Union'. Paper presented at the workshop 'Transposition and Compliance in the European Union', 11-13 June, Oud-Poelgeest, Leiden, the Netherlands.

Bursens, P. (2002) 'Why Denmark and Belgium have different implementation records: on transposition laggards and leaders in the EU', Scandinavian Political Studies 25(2): 173-95.

Coates, D. (1984) 'Food law. Brussels, Whitehall and town hall', in D. Lewis, and H. Wallace (eds), Policies into Practice. National and International Case Studies in Implementation, London and Exeter: Heinemann, pp. 144-60.

European Commission (2003a) 'Internal Market Scoreboard Nr 12'.

European Commission (2003b) 'Internal Market: further deterioration in member states' implementation of rules', Press release, 19 September.

European Commission (2004a) 'Electronic Communications: Commission takes second legal step against eight member states for not adopting new privacy rules for digital networks and services', Press release, 1 April.

European Commission (2004b) 'Six member states face Court action for failing to put in place new rules on electronic communications', Press release, 21 April.

European Commission (2004c) 'Opening up of energy markets: 18 member states still have to transpose the new EU rules', Press release, 13 October.

European Commission (2005) 'Second implementation report of the Internal Market Strategy 2003-2006'.

Falkner, G., Hartlapp, M., Leiber, S. and Treib, O. (2004) 'Non-compliance with EU directives in the member states: opposition through the backdoor?', West European Politics 27(3): 452-73.

Falkner, G., Treib, O., Hartlapp, M. and Leiber, S. (2005) Complying with Europe: EU Harmonisation and Soft Law in the Member States, Cambridge: Cambridge University Press.

Featherstone, K. and Radaelli, C. (eds) (2003) The Politics of Europeanization, Oxford: Oxford University Press.

Giuliani, M. (2003) 'Europeanization in comparative perspective: institutional fit and national adaptation', in K. Featherstone and C. Radaelli (eds), The Politics of Europeanization, Oxford: Oxford University Press, pp. 134-58.

Giuliani, M. (2004) 'EU compliance: macro, meso, micro or no institutions at all?', URGE Working Papers No. 6/2004, Moncalieri (Turin): Research Unit on European Governance.

Golub, J. (1999) 'In the shadow of the vote? Decision making in the European Community', International Organization 53(4): 733-64.

Green Cowles, M., Caporaso, J. and Risse, T. (eds) (2001) Transforming Europe: Europeanization and Domestic Change, Ithaca and London: Cornell University Press.

Haas, P.M. (1998) 'Compliance with EU directives: insights from international relations and comparative politics', Journal of European Public Policy 5(1): 17-37.

Haverland, M. and Romeijn, M. (2006) 'Do member states make European policies work? Analysing the EU transposition deficit'. Working paper, Leiden University/ Nijmegen University.

Héritier, A., Kerwer, D., Knill, C., Lehmkuhl, D., Teutsch, M. and Douillet, A-C. (2001) Differential Europe: The European Union Impact on National Policymaking, Lanham: Rowman \& Littlefield.

International Institute for Management and Development (1996-2003) The World Competitiveness Yearbook, Lausanne.

Kaeding, M. (2005) 'Determinants of transposition delay in the European Union'. Paper presented at the ECPR Joint Sessions, 14-19 April, Granada, Spain. 
Kaufmann, D., Kraay, A. and Mastruzzi, M. (2003) 'Governance matters III: Governance indicators for 1996-2002', World Bank Policy Research Working Paper 3106, Washington, DC: The World Bank.

Knill, C. and Lenschow, A. (1998) 'Coping with Europe: the impact of British and German administrations on the implementation of EU environmental policy', Journal of European Public Policy 5(4): 595-614.

Lampinen, R. and Uusikylä, P. (1998) 'Implementation deficit-why member states do not comply with EU directives', Scandinavian Political Studies 21(3): 231-51.

March, J.G. (1994) A Primer on Decision Making: How Decisions Happen, New York: The Free Press.

March, J.G. and Olsen, J.P. (1989) Rediscovering Institutions: The Organizational Basis of Politics, New York: The Free Press.

Mastenbroek, E. (2003) 'Surviving the deadline: the transposition of EU directives in the Netherlands', European Union Politics 4(4): 371-95.

Mastenbroek, E. (2005a) 'Europa tegen heug en meug? De omzetting van richtlijnen in Nederland', Beleid en Maatschappij 32(1): 13-23.

Mastenbroek, E. (2005b) 'EU compliance: still a "black hole?"', Journal of European Public Policy 12(6): 1103-20.

Mbaye, H.A.D. (2001) 'Why national states comply with supranational law: explaining implementation infringements in the European Union, 1972-1993', European Union Politics 2(3): 259-81.

Mény, Y., Muller, P. and Quermonne, J-L. (eds) (1996) Adjusting to Europe: The Impact of the European Union on National Institutions and Politics, London: Routledge.

Miles, J. and Shelvin, M. (2001) Applying Regression and Correlation: A Guide for Students and Researchers, London: Sage .

NRC Handelsblad (1997a) 'Brussel onvolledig ingelicht; bijna 400 wetten en regels ongeldig', NRC Handelsblad, 6 June.

NRC Handelsblad (1997b)'Richtlijn 83/189 zaait paniek', NRC Handelsblad, 6 June.

NRC Handelsblad (1997c) 'Hersteloperatie om ongeldigheid wetten en regels', NRC Handelsblad, 7 June.

NRC Handelsblad (1997d) 'EC: Securitel-probleem in drie maanden op te lossen', NRC Handelsblad, 7 June.

Steunenberg, B. and Rhinard, M. (2005) 'Hare or turtle? Member states catching up with the transposition of EU directives'. Paper presented at the conference of the Netherlands Institute of Government, 11 November, Nijmegen, the Netherlands.

Sverdrup, U. (2004a) 'Compliance and conflict management in the European Union: Nordic exceptionalism', Scandinavian Political Studies 27(1): 23-43.

Sverdrup, U. (2004b) 'Compliance: a matter of ability?' Paper presented at the workshop 'Transposition and Compliance in the European Union', 11-13 June, OudPoelgeest, Leiden, the Netherlands.

Tallberg, J. (2002) 'Paths to compliance: enforcement, management, and the European Union', International Organization 56(3): 609-43.

van Waarden, F. (2006) 'Taste, traditions, transactions, and trust. The public and private regulation of food', in C. Ansell and D. Vogel (eds), What's the Beef? The Contested Governance of European Food Safety, Cambridge, MA: MIT Press, pp. 35-59.

Final version accepted for publication 16/03/06 